\title{
Corruption Perception Index (CPI), as an Index of Economic Growth for European Countries
}

\author{
Papageorgiou Christos ${ }^{1}$, Kalamara Eleni' ${ }^{2}$, Komninos Dimitrios², Dermatis Zacharias², \\ Anastasiou Athanasios ${ }^{2}$, Liargovas Panagiotis ${ }^{2}$ \\ ${ }^{1}$ Professional Studies, Middlesex University, London, UK \\ ${ }^{2}$ Department of Economic Studies, University of Peloponnese, Workshop of Sustainable Development and Entrepreneurship, \\ Peloponnese, Greece \\ Email: *athanastas@uop.gr
}

How to cite this paper: Christos, P., Eleni, K., Dimitrios, K., Zacharias, D., Athanasios, A. and Panagiotis, L. (2018) Corruption Perception Index (CPI), as an Index of Economic Growth for European Countries. Theoretical Economics Letters, 8, 524-537. https://doi.org/10.4236/tel.2018.83037

Received: January 12, 2018

Accepted: February 11, 2018

Published: February 14, 2018

Copyright $\odot 2018$ by authors and Scientific Research Publishing Inc. This work is licensed under the Creative Commons Attribution International License (CC BY 4.0).

http://creativecommons.org/licenses/by/4.0/

\begin{abstract}
Corruption is a political, economic, cultural and moral problem and it is considered as a universal phenomenon that exists in all developed and developing countries, in public and private sectors, as well as in non-profit and charity organizations. The aim of this study is to investigate the phenomenon of corruption in relation to the economic development and growth in European countries in general and specifically in the European Economic Area, the European Union, the Euro-zone and the non-European Union countries in Central and Eastern Europe, including Turkey. Our objective is specifically the examination of the relationship between corruption and per capita GDP, and between changes in corruption and per capita GDP growth rate. The survey shows that there is a strong inverse relationship between the level of corruption and the per capita GDP of almost all European countries, with the exception the non-European Union countries in the Central and Eastern Europe, including Turkey. Additionally, there is a positive linear relationship between the per capita GDP growth rate and the reduction in corruption levels for all categories of European countries.
\end{abstract}

\section{Keywords}

Corruption, Corruption Index, Economic Growth, GDP Per Capita, Per Capita GDP Growth Rate, European Countries

\section{Introduction-Measuring Corruption Perception}

The corruption perception is based on subjective experiences of individuals or groups. Therefore, the measurement of corruption is carried out by specialized 
business groups through appropriate questionnaires. The survey results are measurable in the form of simple or composite indicators [1]. Some of them are:

- The Corruption Perception Index (CPI), which is a composite index, has measured annually by the international non-governmental Transparency International' organization, since 1995, and records the level of perceived corruption in the public sector by citizens and specific organizations.

- The Control of Corruption Index (CCI), which is a composite index, has released every six months by the World Bank', since 1996, and focuses on public corruption, using survey data from individuals and organizations outside the World Bank.

- The index of Business International (BI), which is measured from data for corruption, collected from around the world by the Economist Intelligence Unit ${ }^{3}$, starting these measurements during the time period 1981-1983.

- The Global Corruption Barometer (GCB), which explores public opinion about corruption and is published annually by the international non-governmental Transparency International ${ }^{\sharp}$ organization since 2003.

- The Bribe Payers Index (BPI), which is based on surveys of senior business and banking executives, is issued by the international non-governmental Transparency Internationa $\bar{P}$ organization and reveals the ability of large companies to bribe public sector and institutions in less developed countries.

- The International Country Risk Guide (ICRG), which analyzes political and financial risk for more than 140 countries and is published monthly by the Political Risk Services Inc ${ }^{6}$.

The Corruption Perception Index (CPI) is the result of the recorded perceptions of the business community and individuals for corruption and is based on 12 sub-indices of specific entities which are listed in Table A1 of the Appendix. At least three surveys are used for each country and currently these surveys cover more than 175 countries. It is considered as a composite index, which is mainly based on the perception of the people or specific institutions about corruption. Starting from 2012, the index takes values from the interval $[0,100], 1$ wherein the value of 0 indicates the maximum corruption, while the value of 100 indicates the sense that there is no corruption at all in the country. This specific index of corruption perception will be used in this paper. However, the use of this index may create some problems when used as an important criterion for the actual levels of corruption in a country [2]:

- Problems due to research methodology, resulting from the lack of a precise

${ }^{1}$ Transparency International, (2016) “Corruption Perception Index 2015”, URL: http://cpi.transparency.org/cpi2015/.

${ }^{2}$ TheWorld Bank, (2016), "Control of Corruption Index", URL: http://www.worldbank.org/.

${ }^{3}$ Economist Intelligence Unit, (2016), “Business International”, URL: http://www.eiu.com/.

${ }^{4}$ Transparency International, (2016), “Global Corruption Barometer 2015”, URL:

http://www.transparency.org/research/gcb/gcb_2015_16.

${ }^{5}$ Transparency International, (2016), "Bribe Payers Index”, URL: http://www.transparency.org/bpi2011.

${ }^{6}$ Political Risk Services Inc., (2016), "International Country Risk Guide”, URL:

https://www.prsgroup.com/about-us/our-two-methodologies/icrg. 
definition of corruption internationally, while the measured final index is the result of a set of sub-indices expressing different forms of corruption.

- Problems due to provision of information from different sources in each country, and biased expression of opinion of individuals.

- Problems of countries ranking by corruption according to the value of the measured index, which often is not comparable with previous years.

\section{Relating Corruption with Per Capita GDP \& Per Capita GDP Growth}

The per capita GDP growth rate is considered as the best indicator of economic growth. However, apart from the per capita GDP growth rate of a country (i), it is also of particular significance whether the per capita GDP $\left(y_{i}\right)$ converges at some level, determined either by some internal criteria, set by the internal country economic policy, or by some acceptable external criteria set for this country. The basic condition for convergence is the negative relation of the per capita GDP growth rate $\left(g_{y i}\right)$ of country $(i)$ and the per capita GDP $\left(y_{i}\right)$ of the same country (i). This relationship as a function has the form:

$$
g_{y i}=f\left(\log y_{i}\right)
$$

where:

$g_{y i}=$ The per capita GDP growth rate of country $(i)$;

$y_{i}=$ The per capita GDP of country $(i)$.

For a constant growth rate $\left(g_{\text {yit } t_{2}}\right)$, Equation (1) is written as:

$$
y_{i t_{2}}=y_{i t_{1}} \mathrm{e}^{g_{y i t_{1} t_{2}}} \Delta t
$$

where:

$g_{\text {yit } t_{2}}=$ The mean per capita GDP growth rate of country $(i)$, during the period of time;

$\Delta t$ (where $\left.\Delta t=t_{2}-t_{1}\right)$

$y_{i t_{1}}=$ The initial per capita GDP of country $(i)$ at time $\left(t_{1}\right)$;

$y_{i t_{2}}=$ The final per capita GDP of country $(i)$ at time $\left(t_{2}\right)$.

And in logarithmic form:

$$
g_{y i t_{1} t_{2}}=\left(\ln y_{i t_{2}}-\ln y_{i t_{1}}\right) / \Delta t
$$

For $\left(t_{1}=t\right)$ and $\left(t_{2}=t+1\right)$, i.e. for a period of time of one year, then $\Delta t=1$ and Equation (3) is written as a logarithmic difference for the estimation of the annual per capita GDP growth rate:

$$
g_{y i t(t+1)}=\ln y_{i(t+1)}-\ln y_{i t}
$$

[3], in order to include socio-economic factors in the calculation of economic growth rate, used an empirical form of Equation (4), which includes a group of socio-economic variables such as schooling, health systems, etc. His equation has the following form [4]:

$$
g_{\text {yit } t_{2}}=a \log y_{i t_{1}}+c X+d
$$


where:

$X=$ A group of variables which include socio-economic effects;

a, $c, d=$ Constants ( $\alpha<0$ for the cases of economic convergence).

Using data of the BI corruption index for 67 countries for the time period 1980-1983, Mauro [5] examined the effect of corruption on economic growth rate and investment. He found that there is a positive relationship between lowlevel corruption and high annual growth rate average during the period 1960 1985. Using empirical data he showed that the improvement of the corruption index by one degree leads to an increase in investments by $5 \%$ of GDP and an increase in the annual growth rate of per capita GDP by $0.5 \%$. Mauro (1995, 1996) extended Barro equation (Equation (5)) for the per capita GDP growth, in order to include the corruption factor as follows [4]:

$$
g_{\text {yit } t_{2}}=a \log y_{i t_{1}}+b \text { Cor }_{i t_{1}}+c X+d
$$

where:

Cor $_{i t_{1}}=$ Corruption index of country $(i)$ at time $\left(\mathrm{t}_{1}\right)$;

$X=$ A group of variables which include socioeconomic effects;

$a, b, c, d=$ Constants $(a<0, b>0)$.

Mauro [6] [7] used the ICRG index for the time period 1982-1995, and the BI index for the time period 1980-1983, for a sample of 106 countries, in order to examine the effect of corruption on growth and investment. He considered the average per capita GDP growth rate and the average investment rate of the time period 1960-1985 for each country as dependent variables. The results showed that the improvement in the corruption index of a country by a single unit causes an increase of more than $4 \%$ in the rate of investment and an increase of more than $0.5 \%$ in the per capita GDP growth rate.

Moreover, Ehrlich [8] studied the effects of corruption on economic growth, based on data for 152 countries for the time period 1960-1992. They found that the higher the level of corruption, the lower the rate of growth, while it became clear that the impact of corruption on economic growth in developed countries is lower.

Similarly, Akçay [4] studied the effect of corruption on growth for 54 developing and developed countries for the time period 1960-1995, using the equation of Mauro (Equation (6)) with a group of eight (X) variables (increase of population, inflation, general government expenditure as a percentage of GDP, ratio of students to teachers, ratio of gross domestic investment to GDP, etc.), and the corruption index ICRG. The results of this study showed that there is a significant positive relationship between low corruption and high economic growth.

\section{Specifying a Correlation between CPI \& GDP Per Capita}

Using elements of corruption perception index CPI and the per capita GDP of 90 to 140 countries for the time period 2001-2005, Shao et al. [9] suggested that there is a positive relationship between index $(C P I)$ and the GDP per capita $(y)$, 
expressed by:

$$
C P I \sim(y)^{\mu}
$$

The positive exponent $(\mu)$ confirms that countries with high per capita GDP are less corrupted, while the per capita GDP of a country may be indicative of the corruption level existing in this country. Shao et al. found that if two countries have a wide difference in their CPI values, then these countries should have similar differences in their per capita GDP, i.e. the higher the value of CPI the higher the per capita GDP. The exponent $(\mu)$ takes a general value of $0.27 \pm 0.02$. Furthermore, Shao et al. studied the relationship between the CPI and the per capita GDP growth rate of four groups of countries according to their per capita income, following the income classification of the World Bank. They found that countries with low corruption (i.e. high values of CPI), show high rates of economic growth (high values of per capita GDP growth rate).

Similarly, Podobnik [10] suggested that the functional dependence can be fit by a power law:

$$
C P I=N(y)^{\mu}
$$

where:

$$
N=\text { Coefficient }(N>0) \text {. }
$$

Using 2006 data, Podobnik [10] found that the value of exponent $(\mu)$ was about 0.23 , while the coefficient $(N)$ was found 0.56 , using the $[0,10]$ scale of CPI.

Furthermore, in order to analyze the dispersion diagrams of the relationship between the average per capita GDP annual growth rate $(g)$ during the five year period 1999-2004 and the change in the value of CPI for the same period of time, [10] used the following relationship:

$$
g_{\text {yit } t_{2} t_{2}}=m \Delta\left(C P I_{i t_{1} t_{2}}\right)+u_{i}
$$

where: $u_{i}=$ Constant.

It was found that for almost all countries in the world, the straight line showed a positive slope $(m)$ equal to 0,09 , which means that the increase of the $[0,10]$ scale of CPI by one unit causes an increase in the average per capita GDP annual growth rate $(g)$ by $1.7 \%$. To estimate the average per capita GDP annual growth rate $(g)$, [10] used Equation (4).

Finally, Vlachos [11] studying the relevant scatter diagram for 172 countries, found that the apparent linear relationship on a log-log scale provided exponent values $(\mu)$ of Equation (8), equal to 0.21 for the period of time 1993-2012. He also found that for low income countries there is no positive exponential relationship between CPI and the average per capita GDP $(y)$. Additionally, for the period of time 2003-2012, and for a total of 119 countries he found that the linear trend line of Equation (9) showed a positive slope $(m)$ equal to 0.149 for all countries, while for the group of high and upper-middle income countries he found a positive slope equal to 0.173 and for the group of lower-medium countries and low-income countries he found a small positive slope equal to 0.042 . 


\section{Examining the Relation of CPI \& Per Capita GDP in European Countries}

In the present study we examined the relationship between corruption and income levels in Europe for the decade 2006-2015. Specifically, we studied i) the relationship between the average per capita GDP $(y)$ at current prices, in \$ U.S. and the average corruption perception index $(C P I)$, during the mentioned time period, and ii) the relation between the average per capita GDP growth rate $(g)$ and the change of the average corruption perception index $[\triangle(C P I)]$ during the same time period. The source of the values for per capita GDP was the Word Bank, while source of the values of CPI was the Transparency International organization. For the purpose of this survey Equations ((8) and (9)) were used, while all used values of CPI before 2012, having values of $[0,10]$ scale, were converted to $[0,100]$ scale in order to obtain compatibility for our analysis.

The groups of European countries used were:

- 43 European countries (all European countries).

- 31 countries member states of the European Economic Area (EEA-31).

- 28 countries member states the European Union (EU-28).

- 19 countries member states of the Euro-zone (EZ-19).

- 12 countries including Turkey and Central and Eastern Europe countries, which are not members of the EU (TCEE-12).

As it is shown in Figure 1 and Table 1, there is generally a positive relationship between the level of corruption $(C P I)$ and the per capita GDP $(y)$, for all European countries, expressed by the value of exponent $(\mu)$, which is equal to 0.3393. This value for the 31 countries of EEA is 0.3451 , for the 28 countries of $\mathrm{EU}$ is 0.3476 and for the 29 countries of EZ is 0.3047 . Generally, it became clear that if two countries within the EEA, the EU or the EZ, differ in the value of CPI, then these countries should differ also in their per capita GDP, so that the country having a higher CPI value (lower perceived corruption), it has also a higher per capita GDP. It was confirmed that there is a statistically significant positive exponential relationship between average CPI and the average per capita GDP, for the majority of European countries. However, for the 12 countries including Turkey and Central and Eastern Europe countries, which are not members of the EU, the exponent values $(\mu)$ is almost 0 (zero), meaning that for these countries, representing the lower income countries of Europe, the level of corruption is not related to the level of per capita GDP.

Concerning the relation between the average per capita GDP growth rate $(g)$, and the change in the average corruption perception index $[\Delta(C P I)]$, as it is shown in Figure 2 and Table 1, there is a positive linear relationship between the average per capita GDP growth rate and the change in the level of corruption, for all European countries, expressed by the slope of a straight line $(\mathrm{m})$ which is 0.0186 . This means that an increase of CPI value by one unit in the [0, 100] corruption scale, will cause an increase in the average per capita GDP annual growth rate by $1.86 \%$. The corresponding values for the 31 countries of 


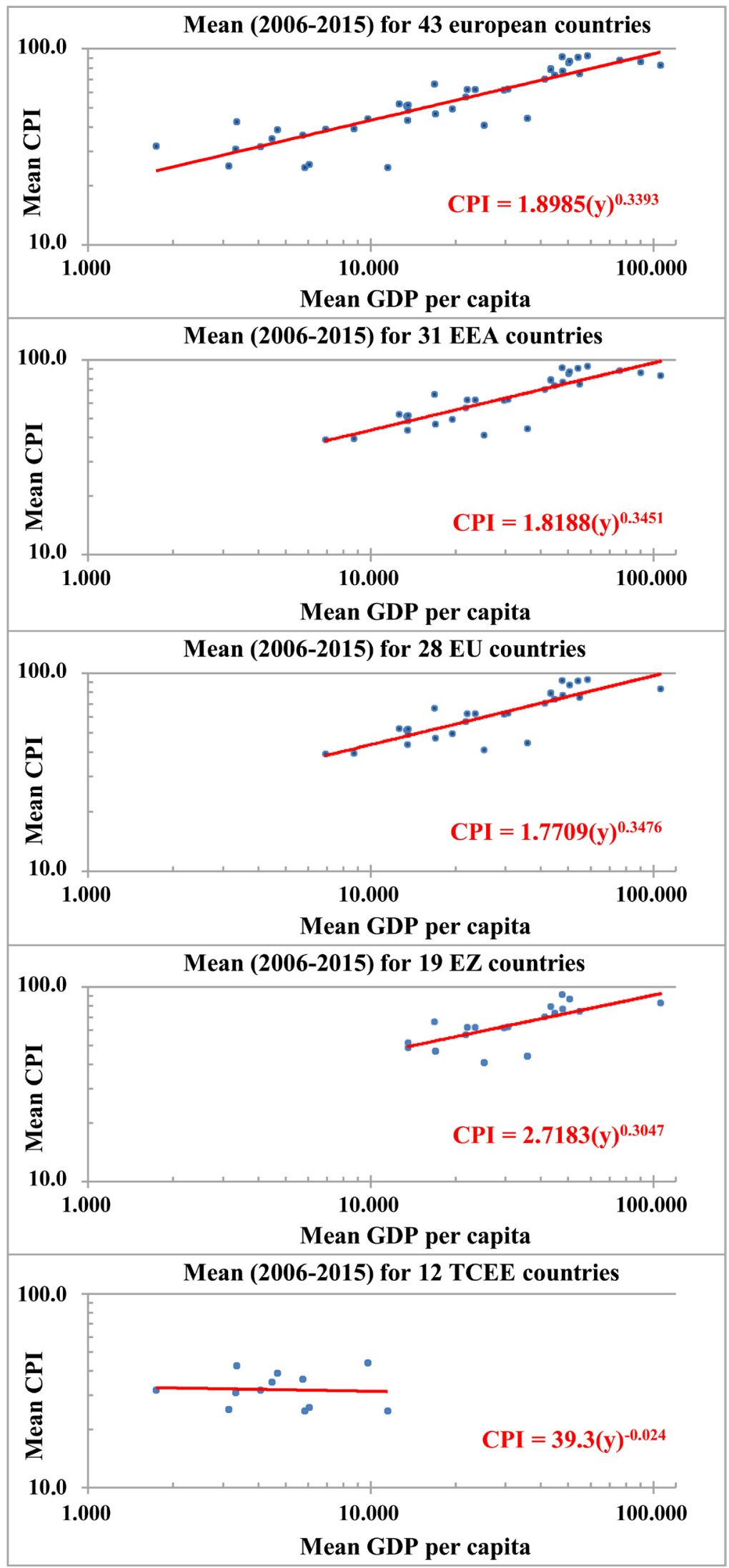

Figure 1. Relation between CPI and GDP per capita. 


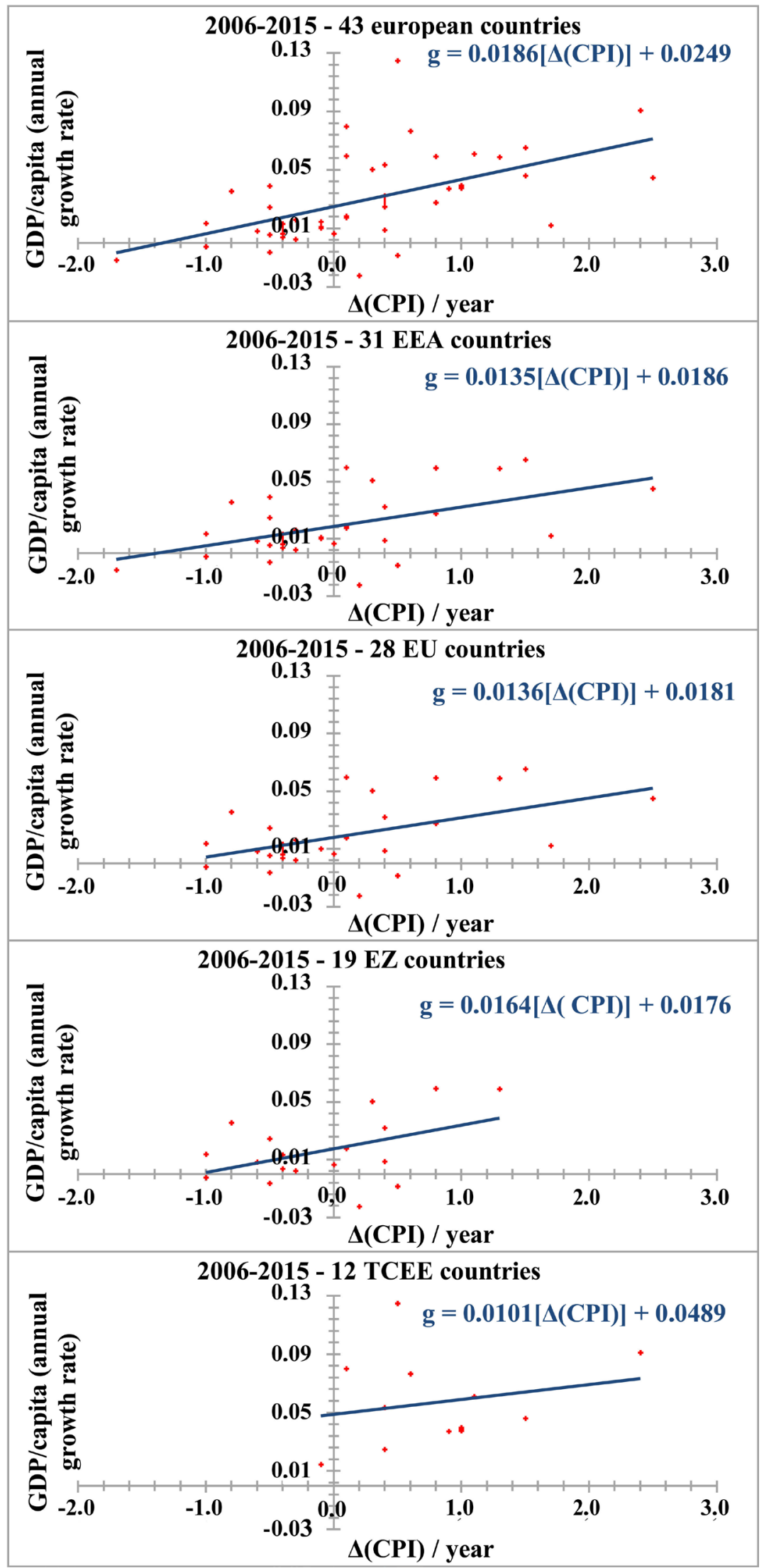

Figure 2. Relation between per capita GDP annual growth rate and $\Delta(\mathrm{CPI}) /$ year. 
Table 1. Summarized results of survey.

\begin{tabular}{ccc}
\hline Group of countries & Exponent $\boldsymbol{\mu}$ (Equation $(8))$ & Slope $\boldsymbol{m}$ (Equation (9)) \\
\hline 43 European countries & 0.3393 & 0.0186 \\
31 EEA countries & 0.3451 & 0.0135 \\
28 EU countries & 0.3476 & 0.0136 \\
19 EZ countries & 0.3047 & 0.0164 \\
12 non-EU TCEE countries & -0.0240 & 0.0101 \\
\hline
\end{tabular}

EEA is $1.35 \%$, for the 28 countries of EU is $1.36 \%$ and for the 19 countries of EZ is $1.64 \%$, showing that there is a statistically significant positive dependence between the per capita GDP growth rate and the change in the CPI. Finally, for the 12 countries including Turkey and Central and Eastern Europe countries, which are not members of the EU, an increase of CPI value by one unit will cause an increase in the average per capita GDP annual growth rate by $1.01 \%$, although the result for the last case is not statistically significant.

\section{Conclusions}

From the previous analysis, we may conclude that there is a positive relationship between the level of corruption and the per capita income, for almost all European countries, with the exception of the non-EU countries of Central and Eastern Europe, including Turkey. This shows that if two countries differ in the value of CPI, then these countries should differ also in their per capita GDP, so that the country having a higher CPI value (lower perceived corruption), it also has a higher per capita GDP.

Additionally, the analysis showed that there is a positive linear relationship between the per capita GDP growth rate and the change in the level of corruption, for all groups of European countries. This leads to the interesting conclusion that reducing the level of corruption in a country causes a significant increase of GDP and wealth of this country.

\section{References}

[1] Mocan, N. (2008) What Determines Corruption? International Evidence from Microdata. Economic Inquiry, Western Economic Association International.

[2] Malito, D.V. (2014) Measuring Corruption Indicators and Indices. EUI Working Papers, RSCAS 2014/13, European University, Institute Robert Schuman Centre for Advanced Studies, Global Governance Programme.

[3] Barro, R. (1991) Economic Growth in a Cross Section of Countries. The Quarterly Journal of Economics, 106, 407-443. https://doi.org/10.2307/2937943

[4] Akçay, S. (2002) Corruption and Economic Growth: Across National Study. Afyon Kocatepe Üniversitesi Iktisadi ve Idari Bilimler Fakültesi, 57, 1-13.

[5] Mauro, P. (1995) Corruption and Growth. The Quarterly Journal of Economics, 110, 681-712. https://doi.org/10.2307/2946696

[6] Mauro, P. (1996) The Effects of Corruption on Growth, Investment, and Government Expenditure. IMF Working Paper, No. 96/98. 
[7] Mauro, P. (1998) Corruption and the Composition of Government Expenditure. Journal of Public Economics, 69, 263-279. https://doi.org/10.1016/S0047-2727(98)00025-5

[8] Ehrlich, I. and Lui, F. (1999) Bureaucratic Corruption and Endogenous Economic Growth. Journal of Political Economy, 107, 54-76. https://doi.org/10.1086/250111

[9] Shao, J., et al. (2007) Quantitative Relations between Corruption and Economic Factors. The European Physical Journal B, 56, 157-166. https://doi.org/10.1140/epjb/e2007-00098-2

[10] Podobnik, S., Shao, J., Njavro, D., Ivanov, P.Ch. and Stanley, H.E. (2008) Influence of Corruption on Economic Growth Rate and Foreign Investment. The European Physical Journal B, 63, 547-550. https://doi.org/10.1140/epjb/e2008-00210-2

[11] Vlachos, I. (2013) Corruption and Economic Growth. Master Degree Dissertation, Department of Economic Studies, University of Peloponnese, Tripolis. 


\section{Appendix Tables}

\section{Appendix 1}

Table A1. Sub-indices for the estimation of corruption perception index (CPI).

\begin{tabular}{cl}
\hline Code & \\
\hline AFDB & African Development Bank-Governance Ratings \\
BF (SGI) & Bertelsmann Foundation-Sustainable Governance Indicators \\
BF (BTI) & Bertelsmann Foundation-Transformation Index \\
IMD & IMD World Competitiveness Yearbook \\
ICRG & Political Risk Services-Country Risk Guide \\
WB & World Bank-Country Performance and Institutional Assessment \\
WEF & World Economic Forum-Executive Opinion Survey \\
WJP & World Justice Project-Rule of Law Index \\
EIU & Economist Intelligence Unit-Country Risk Assessment \\
GI & Global Insight-Country Risk Ratings \\
PERC & Political and Economic Risk Consultancy-Asian Intelligence \\
FH & Freedom House-Nations in Transit
\end{tabular}

Source: Transparency International (2016).

\section{Appendix 2. Corruption Perception Indices of European Countries}

Table A2. Corruption perception indices of all European countries for years 2005-2015.

\begin{tabular}{|c|c|c|c|c|c|c|c|c|c|c|c|c|}
\hline \multirow{2}{*}{ Country } & \multirow{2}{*}{ Code } & \multicolumn{11}{|c|}{ CPI } \\
\hline & & 2005 & 2006 & 2007 & 2008 & 2009 & 2010 & 2011 & 2012 & 2013 & 2014 & 2015 \\
\hline Albania & ALB & 24.0 & 26.0 & 29.0 & 34.0 & 32.0 & 33.0 & 31.0 & 33.0 & 31.0 & 33.0 & 36.0 \\
\hline Armenia & ARM & 29.0 & 29.0 & 30.0 & 29.0 & 27.0 & 26.0 & 26.0 & 34.0 & 36.0 & 37.0 & 35.0 \\
\hline Austria & AUT & 87.0 & 86.0 & 81.0 & 81.0 & 79.0 & 79.0 & 78.0 & 69.0 & 69.0 & 72.0 & 76.0 \\
\hline Azerbaijan & AZE & 22.0 & 24.0 & 21.0 & 19.0 & 23.0 & 24.0 & 24.0 & 27.0 & 28.0 & 29.0 & 29.0 \\
\hline Belarus & BLR & 26.0 & 21.0 & 21.0 & 20.0 & 24.0 & 25.0 & 24.0 & 31.0 & 29.0 & 31.0 & 32.0 \\
\hline Belgium & BEL & 74.0 & 73.0 & 71.0 & 73.0 & 71.0 & 71.0 & 75.0 & 75.0 & 75.0 & 76.0 & 77.0 \\
\hline Bosnia \& Herzegovina & $\mathrm{BIH}$ & 29.0 & 29.0 & 33.0 & 32.0 & 30.0 & 32.0 & 32.0 & 42.0 & 42.0 & 39.0 & 38.0 \\
\hline Bulgaria & BGR & 40.0 & 40.0 & 41.0 & 36.0 & 38.0 & 36.0 & 33.0 & 41.0 & 41.0 & 43.0 & 41.0 \\
\hline Croatia & HRV & 34.0 & 34.0 & 41.0 & 44.0 & 41.0 & 41.0 & 40.0 & 46.0 & 48.0 & 48.0 & 51.0 \\
\hline Cyprus & CYP & 57.0 & 56.0 & 53.0 & 64.0 & 66.0 & 63.0 & 63.0 & 66.0 & 63.0 & 63.0 & 61.0 \\
\hline Czech Republic & CZE & 43.0 & 48.0 & 52.0 & 52.0 & 49.0 & 46.0 & 44.0 & 49.0 & 48.0 & 51.0 & 56.0 \\
\hline Denmark & DNK & 95.0 & 95.0 & 94.0 & 93.0 & 93.0 & 93.0 & 94.0 & 90.0 & 91.0 & 92.0 & 91.0 \\
\hline Estonia & EST & 64.0 & 67.0 & 65.0 & 66.0 & 66.0 & 65.0 & 64.0 & 64.0 & 68.0 & 69.0 & 70.0 \\
\hline Finland & FIN & 96.0 & 96.0 & 94.0 & 90.0 & 89.0 & 92.0 & 94.0 & 90.0 & 89.0 & 89.0 & 90.0 \\
\hline
\end{tabular}




\begin{tabular}{|c|c|c|c|c|c|c|c|c|c|c|c|c|}
\hline France & FRA & 75.0 & 74.0 & 73.0 & 69.0 & 69.0 & 68.0 & 70.0 & 71.0 & 71.0 & 69.0 & 70.0 \\
\hline Georgia & GEO & 23.0 & 28.0 & 34.0 & 39.0 & 41.0 & 38.0 & 41.0 & 52.0 & 49.0 & 52.0 & 52.0 \\
\hline Germany & DEU & 82.0 & 80.0 & 78.0 & 79.0 & 80.0 & 79.0 & 80.0 & 79.0 & 78.0 & 79.0 & 81.0 \\
\hline Greece & GRC & 43.0 & 44.0 & 46.0 & 47.0 & 38.0 & 35.0 & 34.0 & 36.0 & 40.0 & 43.0 & 46.0 \\
\hline Hungary & HUN & 50.0 & 52.0 & 53.0 & 51.0 & 51.0 & 47.0 & 46.0 & 55.0 & 54.0 & 54.0 & 51.0 \\
\hline Iceland & ISL & 97.0 & 96.0 & 92.0 & 89.0 & 87.0 & 85.0 & 83.0 & 82.0 & 78.0 & 79.0 & 79.0 \\
\hline Ireland & IRL & 74.0 & 74.0 & 75.0 & 77.0 & 80.0 & 80.0 & 75.0 & 69.0 & 72.0 & 74.0 & 75.0 \\
\hline Italy & ITA & 50.0 & 49.0 & 52.0 & 48.0 & 43.0 & 39.0 & 39.0 & 42.0 & 43.0 & 43.0 & 44.0 \\
\hline Kazakhstan & $\mathrm{KAZ}$ & & & & & & & & 28.0 & 26.0 & 29.0 & 28.0 \\
\hline Kosovo & KSV & & & & & & 28.0 & 29.0 & 34.0 & 33.0 & 33.0 & 33.0 \\
\hline Latvia & LVA & 42.0 & 47.0 & 48.0 & 50.0 & 45.0 & 43.0 & 42.0 & 49.0 & 53.0 & 55.0 & 55.0 \\
\hline Liechtenstein & LIE & & & & & & & & & & & \\
\hline Lithuania & LTU & 48.0 & 48.0 & 48.0 & 46.0 & 49.0 & 50.0 & 48.0 & 54.0 & 57.0 & 58.0 & 61.0 \\
\hline Luxembourg & LUX & 85.0 & 86.0 & 84.0 & 83.0 & 82.0 & 85.0 & 85.0 & 80.0 & 80.0 & 82.0 & 81.0 \\
\hline Macedonia FYR & MKD & 27.0 & 27.0 & 33.0 & 36.0 & 38.0 & 41.0 & 39.0 & 43.0 & 44.0 & 45.0 & 42.0 \\
\hline Malta & MLT & 66.0 & 64.0 & 58.0 & 58.0 & 52.0 & 56.0 & 56.0 & 57.0 & 56.0 & 55.0 & 56.0 \\
\hline Moldova & MDA & 29.0 & 32.0 & 28.0 & 29.0 & 33.0 & 29.0 & 29.0 & 36.0 & 35.0 & 35.0 & 33.0 \\
\hline Montenegro & MNE & & & 33.0 & 34.0 & 39.0 & 37.0 & 40.0 & 41.0 & 44.0 & 42.0 & 44.0 \\
\hline Netherlands & NLD & 86.0 & 87.0 & 90.0 & 89.0 & 89.0 & 88.0 & 89.0 & 84.0 & 83.0 & 83.0 & 87.0 \\
\hline Norway & NOR & 89.0 & 88.0 & 87.0 & 79.0 & 86.0 & 86.0 & 90.0 & 85.0 & 86.0 & 86.0 & 87.0 \\
\hline Poland & POL & & 37.0 & 42.0 & 46.0 & 50.0 & 53.0 & 55.0 & 58.0 & 60.0 & 61.0 & 62.0 \\
\hline Portugal & PRT & 65.0 & 66.0 & 65.0 & 61.0 & 58.0 & 60.0 & 61.0 & 63.0 & 62.0 & 63.0 & 63.0 \\
\hline Romania & ROU & 30.0 & 31.0 & 37.0 & 38.0 & 38.0 & 37.0 & 36.0 & 44.0 & 43.0 & 43.0 & 46.0 \\
\hline Russia & RUS & 24.0 & 25.0 & 23.0 & 21.0 & 22.0 & 21.0 & 24.0 & 28.0 & 28.0 & 27.0 & 29.0 \\
\hline Serbia (\& Montenegro) & SRB & 28.0 & 30.0 & 34.0 & 34.0 & 35.0 & 35.0 & 33.0 & 39.0 & 42.0 & 41.0 & 40.0 \\
\hline Slovakia & SVK & 43.0 & 47.0 & 49.0 & 50.0 & 45.0 & 43.0 & 40.0 & 46.0 & 47.0 & 50.0 & 51.0 \\
\hline Slovenia & SVN & 61.0 & 64.0 & 66.0 & 67.0 & 66.0 & 64.0 & 59.0 & 61.0 & 57.0 & 58.0 & 60.0 \\
\hline Spain & ESP & 70.0 & 68.0 & 67.0 & 65.0 & 61.0 & 61.0 & 62.0 & 65.0 & 59.0 & 60.0 & 58.0 \\
\hline Sweden & SWE & 92.0 & 92.0 & 93.0 & 93.0 & 92.0 & 92.0 & 93.0 & 88.0 & 89.0 & 87.0 & 89.0 \\
\hline Switzerland & $\mathrm{CHE}$ & 91.0 & 91.0 & 90.0 & 90.0 & 90.0 & 87.0 & 88.0 & 86.0 & 85.0 & 86.0 & 86.0 \\
\hline Turkey & TUR & 35.0 & 38.0 & 41.0 & 46.0 & 44.0 & 44.0 & 42.0 & 49.0 & 50.0 & 45.0 & 42.0 \\
\hline Ukraine & UKR & 26.0 & 28.0 & 27.0 & 25.0 & 22.0 & 24.0 & 23.0 & 26.0 & 25.0 & 26.0 & 27.0 \\
\hline $\begin{array}{l}\text { United Kingdom } \\
\text { Data Not a }\end{array}$ & $\begin{array}{c}\text { GBR } \\
\text { vailabl }\end{array}$ & $86.0 \mathrm{e}$ & 86.0 & 84.0 & 77.0 & 77.0 & 76.0 & 78.0 & 74.0 & 76.0 & 78.0 & 81.0 \\
\hline
\end{tabular}

Source: Transparency International (2016). 


\section{Appendix 3. GDP per capita of European Countries}

Table A3. GDP per capita of all European countries for years 2005-2015 (current U.S. \$).

\begin{tabular}{|c|c|c|c|c|c|c|c|c|c|c|c|c|}
\hline \multirow{2}{*}{ Country } & \multirow{2}{*}{ Code } & \multicolumn{11}{|c|}{ GDP per capita } \\
\hline & & 2005 & 2006 & 2007 & 2008 & 2009 & 2010 & 2011 & 2012 & 2013 & 2014 & 2015 \\
\hline Albania & ALB & 2.709 & 3.005 & 3.603 & 4.371 & 4.114 & 4.094 & 4.438 & 4.248 & 4.412 & 4.569 & 3.945 \\
\hline Armenia & $\mathrm{ARM}$ & 1.625 & 2.127 & 3.081 & 3.920 & 2.916 & 3.125 & 3.417 & 3.566 & 3.717 & 3.862 & 3.489 \\
\hline Austria & AUT & 38.242 & 40.431 & 46.587 & 51.386 & 47.654 & 46.660 & 51.124 & 48.334 & 50.505 & 51.323 & 43.775 \\
\hline Azerbaijan & AZE & 1.578 & 2.473 & 3.851 & 5.575 & 4.950 & 5.843 & 7.190 & 7.394 & 7.812 & 7.886 & 5.496 \\
\hline Belarus & BLR & 3.126 & 3.849 & 4.736 & 6.376 & 5.176 & 5.819 & 6.306 & 6.722 & 7.722 & 8.025 & 5.740 \\
\hline Belgium & BEL & 36.967 & 38.852 & 44.404 & 48.425 & 44.881 & 44.383 & 47.700 & 44.741 & 46.508 & 47.347 & 40.324 \\
\hline Bosnia \& Herzegovina & $\mathrm{BIH}$ & 2.928 & 3.352 & 4.108 & 4.975 & 4.586 & 4.475 & 4.861 & 4.495 & 4.748 & 4.852 & 4.249 \\
\hline Bulgaria & BGR & 3.853 & 4.456 & 5.933 & 7.296 & 6.956 & 6.843 & 7.814 & 7.378 & 7.675 & 7.853 & 6.993 \\
\hline Croatia & HRV & 10.224 & 11.363 & 13.547 & 15.894 & 14.157 & 13.509 & 14.542 & 13.236 & 13.575 & 13.481 & 11.536 \\
\hline Cyprus & CYP & 25.324 & 27.170 & 31.387 & 35.391 & 32.106 & 30.818 & 32.234 & 28.951 & 27.908 & 27.341 & 23.243 \\
\hline Czech Republic & CZE & 13.318 & 15.159 & 18.334 & 22.649 & 19.698 & 19.764 & 21.717 & 19.730 & 19.916 & 19.745 & 17.548 \\
\hline Denmark & DNK & 48.817 & 52.041 & 58.501 & 64.182 & 57.896 & 57.648 & 61.304 & 58.125 & 60.362 & 61.331 & 51.989 \\
\hline Estonia & EST & 10.338 & 12.595 & 16.586 & 18.095 & 14.726 & 14.639 & 17.454 & 17.422 & 19.030 & 19.941 & 17.119 \\
\hline Finland & FIN & 38.969 & 41.121 & 48.289 & 53.401 & 47.107 & 46.205 & 50.788 & 47.416 & 49.638 & 49.888 & 42.311 \\
\hline France & FRA & 34.880 & 36.545 & 41.601 & 45.413 & 41.631 & 40.706 & 43.807 & 40.838 & 42.571 & 42.697 & 36.206 \\
\hline Georgia & GEO & 1.530 & 1.873 & 2.492 & 3.175 & 2.707 & 2.964 & 3.725 & 4.143 & 4.274 & 4.430 & 3.796 \\
\hline Germany & DEU & 34.697 & 36.448 & 41.815 & 45.699 & 41.733 & 41.788 & 45.936 & 44.065 & 45.688 & 47.903 & 41.313 \\
\hline Greece & GRC & 22.552 & 24.801 & 28.827 & 31.997 & 29.711 & 26.919 & 25.915 & 22.243 & 21.875 & 21.674 & 18.002 \\
\hline Hungary & HUN & 11.162 & 11.39 & 13.843 & 15.669 & 12.967 & 13.026 & 14.049 & 12.834 & 13.614 & 14.118 & 12.364 \\
\hline Iceland & ISL & 56.446 & 56.09 & 68.345 & 55.230 & 40.362 & 41.620 & 45.971 & 44.259 & 47.493 & 52.037 & 50.173 \\
\hline Ireland & IRL & 50.887 & 54.32 & 61.388 & 61.235 & 51.984 & 48.541 & 52.564 & 49.231 & 52.035 & 55.503 & 61.134 \\
\hline Italy & ITA & 31.959 & 33.41 & 37.699 & 40.640 & 36.977 & 35.852 & 38.332 & 34.814 & 35.370 & 35.365 & 29.958 \\
\hline Kazakhstan & KAZ & & & & & & & & 12.387 & 13.891 & 12.807 & 10.510 \\
\hline Kosovo & KSV & & & & & & 3.283 & 3.737 & 3.601 & 3.890 & 4.074 & 3.562 \\
\hline Latvia & LVA & 7.559 & 9.668 & 14.044 & 16.349 & 12.219 & 11.330 & 13.798 & 13.799 & 15.033 & 15.710 & 13.649 \\
\hline Liechtenstein & LIE & & & & & & & & & & & \\
\hline Lithuania & LTU & 7.863 & 9.241 & 12.298 & 14.962 & 11.837 & 11.989 & 14.367 & 14.343 & 15.692 & 16.490 & 14.147 \\
\hline Luxembourg & LUX & 79.494 & 88.68 & 104.841 & 112.851 & 101.222 & 103.267 & 113.240 & 105.447 & 113.727 & 116.613 & 101.450 \\
\hline Macedonia FYR & MKD & 3.064 & 3.351 & 4.064 & 4.822 & 4.566 & 4.561 & 5.080 & 4.710 & 5.220 & 5.453 & 4.853 \\
\hline Malta & MLT & 15.835 & 16.67 & 19.376 & 21.929 & 20.676 & 21.088 & 22.957 & 22.082 & 24.057 & 25.125 & 22.596 \\
\hline Moldova & $\mathrm{MDA}$ & 831 & 951 & 1.230 & 1.696 & 1.526 & 1.632 & 1.971 & 2.047 & 2.244 & 2.245 & 1.848 \\
\hline Montenegro & MNE & & & 5.957 & 7.326 & 6.698 & 6.682 & 7.319 & 6.587 & 7.187 & 7.378 & 6.406 \\
\hline Netherlands & NLD & 41.577 & 44.45 & 51.241 & 56.929 & 51.900 & 50.341 & 53.537 & 49.475 & 51.574 & 52.157 & 44.300 \\
\hline Norway & NOR & 66.775 & 74.11 & 85.129 & 96.881 & 80.018 & 87.646 & 100.575 & 101.564 & 102.910 & 97.005 & 74.400 \\
\hline
\end{tabular}




\section{Continued}

\begin{tabular}{ccccccccccccc}
\hline Poland & POL & 8.021 & 9.041 & 11.260 & 14.001 & 11.528 & 12.600 & 13.893 & 13.145 & 13.781 & 14.342 & 12.555 \\
Portugal & PRT & 18.785 & 19.82 & 22.780 & 24.816 & 23.064 & 22.540 & 23.195 & 20.577 & 21.619 & 22.124 & 19.222 \\
Romania & ROU & 4.676 & 5.829 & 8.214 & 10.136 & 8.220 & 8.297 & 9.200 & 8.558 & 9.585 & 10.020 & 8.973 \\
Russia & RUS & 5.323 & 6.920 & 9.101 & 11.635 & 8.563 & 10.675 & 14.228 & 15.042 & 15.552 & 14.052 & 9.093 \\
Serbia (\& Montenegro) & SRB & 3.528 & 4.130 & 5.458 & 6.702 & 5.821 & 5.412 & 6.423 & 5.659 & 6.354 & 6.200 & 5.235 \\
Slovakia & SVK & 11.669 & 13.13 & 16.058 & 18.650 & 16.513 & 16.602 & 18.186 & 17.275 & 18.192 & 18.595 & 16.088 \\
Slovenia & SVN & 18.169 & 19.72 & 23.841 & 27.502 & 24.634 & 23.439 & 24.984 & 22.486 & 23.150 & 24.021 & 20.727 \\
Spain & ESP & 26.511 & 28.48 & 32.709 & 35.579 & 32.333 & 30.738 & 31.832 & 28.648 & 29.371 & 29.719 & 25.832 \\
Sweden & SWE & 43.085 & 46.25 & 53.324 & 55.747 & 46.207 & 52.076 & 59.594 & 57.134 & 60.283 & 59.180 & 50.580 \\
Switzerland & CHE & 54.798 & 57.34 & 63.223 & 72.120 & 69.672 & 74.277 & 88.003 & 83.164 & 84.659 & 85.815 & 80.945 \\
Turkey & TUR & 7.117 & 7.727 & 9.309 & 10.382 & 8.624 & 10.111 & 10.539 & 10.539 & 10.801 & 10.304 & 9.126 \\
Ukraine & UKR & 1.829 & 2.303 & 3.069 & 3.891 & 2.545 & 2.965 & 3.570 & 3.855 & 4.030 & 3.105 & 2.115 \\
United Kingdom & GBR & 41.524 & 44.01 & 49.949 & 46.523 & 38.010 & 38.709 & 41.243 & 41.538 & 42.407 & 46.412 & 43.876 \\
\hline
\end{tabular}

Source: World Bank (2016). The World Bank, (2016), “GPD per capita, (current US\$)”, URL: http://data.worldbank.org/indicator/NY.GDP.PCAP.CD. 